\title{
The Blood of Christ Compels Them: State Religiosity and State Population Mobility During the Coronavirus (COVID-19) Pandemic
}

\author{
Terrence D. Hill ${ }^{1}$ D $\cdot$ Kelsey Gonzalez ${ }^{1} \cdot$ Amy M. Burdette $^{2}$
}

Published online: 28 June 2020

(c) Springer Science+Business Media, LLC, part of Springer Nature 2020

\begin{abstract}
This paper examines the association between state religiosity and population mobility during the coronavirus (COVID-19) pandemic. We use first-party geo-behavioral data collected through mobile phone operating systems, global positioning systems, and Wi-Fi signals to assess changes in the average median distance traveled by approximately 15,000,000 devices over eight weeks (February 24-April 13) in the contiguous United States. Robust regression results show that more religious states tend to exhibit higher average mobility scores and slower average declines in mobility. Findings also suggest that state stay-at-home orders have a weaker impact on mobility in more religious states.
\end{abstract}

Keywords Religion · Religiosity $\cdot$ Mobility $\cdot$ Coronavirus $\cdot$ COVID-19

\section{Introduction}

After spreading around the world in a matter of months, the coronavirus (COVID19) has become a leading cause of death in the United States. According to recent reports, COVID-19 "deaths have snowballed from a few isolated cases to thousands across the country each day" (Keating and Esteban 2020). Although the Centers for Disease Control and Prevention (CDC) (2020) have proposed several potential

Terrence D. Hill

tdhill@email.arizona.edu

Kelsey Gonzalez

kelseygonzalez@email.arizona.edu

Amy M. Burdette

aburdette@fsu.edu

1 School of Sociology, The University of Arizona, Social Sciences Building, Room 400, 1145 E.

South Campus Drive, P.O. Box 210027, Tucson, AZ 85721, USA

2 Department of Sociology, Florida State University, 526 Bellamy Building, Tallahassee,

FL 32306-2270, USA 
mitigation strategies, social distancing and staying at home have received the most national attention. CDC officials and frontline health care professionals advise that the best way to prevent exposure to the virus is to stay at home and to avoid close contact with people. As the official website of the Hopi Tribe (2020) explains, "the virus does not move, people move it...if people stop moving, the virus stops moving and dies." If staying at home is so important for slowing the spread of the coronavirus, we must begin to consider the social patterning of mobility (i.e., how far people are traveling from home in their daily lives). The fundamental question is whether certain populations travel more or less than others during the pandemic.

In this paper, we consider the association between state religiosity and state mobility scores. Over the past several weeks, the institution of religion has received a great deal of media attention and public scrutiny. On March 18, Newsweek reported that "Pastor Holds Service with over 1000 Parishioners in Defiance of Large-Gathering Ban" (Slisco 2020). On March 19, The Washington Post advised that "Coronavirus Deniers and Hoaxers Persist despite Dire Warnings, Claiming 'it's Mass Hysteria"" (Gowen 2020). On March 27, The New York Times suggested that "The Religious Right's Hostility to Science is Crippling our Coronavirus Response" (Stewart 2020). Although not representative of the religious spectrum in this country, all of these stories (and many more like them) seem to point to the same general conclusion: Religious populations and communities may be especially likely to acquire and spread the coronavirus.

In the pages that follow, we explore relevant research from the sociology of religion and recent religious rhetoric surrounding the coronavirus pandemic. We then model state mobility scores as a function of state religiosity and covariates. After summarizing our key results, we discuss the contributions and limitations of our study. We end with important directions for future research on the social patterning of mobility during the coronavirus pandemic.

\section{Religion, Science, and the Pandemic}

Our central argument is that more religious populations may be especially resistant to public health recommendations during the coronavirus pandemic (e.g., social distancing and staying at home) because they hold more negative views of science and scientists and strong religious beliefs concerning the pandemic itself. Several studies show that more religious populations tend to report less trust in science as a social institution and more anti-science attitudes (Evans 2013; Gauchat 2008, 2012). Of course, these positions are not representative of all religious groups. There is at least some evidence to suggest that more conservative-leaning Protestant denominations may be less literate in science and especially critical of the scientific community and the potential benefits of scientific progress (Ellison and Musick 1995; Evans 2013; Gauchat 2008; Sherkat 2011, 2017). For example, studies show that conservative Protestants are often less concerned with environmental degradation, less trusting of the findings of climate scientists, and more likely to endorse "a polluting creed" (Sherkat and Ellison 2007; Smiley 2019). 
Many conservative Protestant denominations see the Bible as the ultimate source of authority and direction when interpreting and experiencing personal life and world events (Boone 1989; Ellison et al. 1996). In contrast to the positivist logic implied by the scientific method, so-called biblical literalists assess the legitimacy of scientific information by its apparent compatibility with scripture (Ellison and Musick 1995). Religious conservatives, guided by pastors and other religious elites, often draw on religious scripture to oppose scientific recommendations that are perceived as immoral or defined as encroaching on religious liberty or the will or grace of God. Moreover, tensions between religion and science are often rooted in fears concerning the profane influence of science on society (Evans 2013) and a "social conflict between institutions struggling for power" (Evans and Evans 2008:97).

Our perspective is that these religious belief systems are likely to serve as an ideological basis for resisting public health recommendations and initiatives during the pandemic. The specific flashpoints appear to center on (1) denying health information from health scientists (mistrust of science), (2) accepting health misinformation from religious and political leaders (religious authority), and (3) rejecting restrictions on in-person religious services (religious liberty). These themes are clearly represented in several recent cases of religious leadership.

Pastor Andrew of the USA Christian Church in California tells us that "our safety is at stake since national disobedience of God's laws brings danger and diseases, such as coronavirus, but obeying God brings covenant protection. God protects the USA from danger as the country repents of LGBT, false gods, abortion and other sins" (Rosen 2020).

Reverend Curtis of Havre Assembly of God Church in Montana refers to COVID19 as an acronym for "Christ Over Viruses and Infectious Diseases" (Curtis 2020). He also directs us to "Joshua 1:9-Be strong and courageous. Do not be frightened, and do not be dismayed, for the Lord your God is with you wherever you go." Based on this passage, he asks, "Shall we deal with fright and dismay with the strength and courage that God prescribes? Shall we face an uncertain future, knowing that God is with us no matter what?"

Reverend Spell of the Life Tabernacle Church in Louisiana is convinced that the virus is "not a concern" because it is "politically motivated" (Slisco 2020). Reverend Spell also expresses faith in the healing powers of his church: "Our church is a hospital where the sick can come and get healing. Cancers are healed here, people are healed of HIV in these services, and we believe that tonight, we're also going to pass out anointed handkerchiefs to people who may have a fear, who may have a sickness, and we believe that when those anointed handkerchiefs go, that healing virtue is going to go on them as well."

Pastor Howard-Browne of The River at Tampa Bay Church in Florida describes people who are concerned about the coronavirus as "pansies" and insists he would only close his church "when the rapture is taking place" (Stewart 2020). Days after making these comments, the pastor was arrested by the sheriff of Hillsborough County because "his reckless disregard for human life put hundreds of people in his congregation at risk and thousands of residents who may interact with them this week in danger" (Mazzei 2020). 
Bishop Glenn of New Deliverance Evangelistic Church in Virginia told his congregation that "God is larger than this dreaded virus" and that "people are healed" in his church (Brown 2020). A few weeks later, the pastor died after being diagnosed with the coronavirus.

Even President Trump has attempted to connect with the rhetoric of religious leadership to push his precarious economic timelines, suggesting that "pews should be filled on Easter," knowing that "his base will revel in the symbolism of resurrection" (Wise 2020). The general concern of health professionals is that churches may become "coronavirus hotspots" because such "meetings are counter to the prescribed public health policy of groups of people coming together" (Gattis 2020). Scholars in public health echo these sentiments, noting "the way people interact in churches, synagogues, mosques and other religious facilities-shaking hands, hugging, singing - appears conducive to what epidemiologists call 'super-spreading events" (Collier et al. 2020). Emboldened by religious leaders and the President, some churchgoers in Missouri have defied social distancing warnings with claims that they are protected from the coronavirus because they are "covered in Jesus' blood" (Edwards 2020).

\section{Hypotheses}

In accordance with these arguments, we developed three hypotheses to guide subsequent analyses. Our first hypothesis (H1) is that more religious states will exhibit higher average mobility scores. In other words, more religious states will tend to travel more than less religious states during the pandemic. This hypothesis will be tested through the direct effect of state religiosity on state mobility scores. Our second hypothesis $(\mathrm{H} 2)$ is that state mobility scores will decline at slower rates in more religious states. The idea is that religious states will be especially reluctant to change their behavior over the study period and that reductions in travel during the pandemic will be, on average, smaller in these states. This hypothesis will be tested through the moderation of state mobility trends (i.e., weekly variations in mobility scores) by state religiosity (i.e., week*religiosity). Our final hypothesis (H3) is that the inverse association between number of days with a state stay-at-home order and mobility scores will be less pronounced in more religious states. This hypothesis will be tested through the interaction of days with a state stay-at-home order and state religiosity (i.e., stay-at-home order*religiosity).

\section{Data}

We employ 8 weeks (February 24-April 13) of first-party mobility data from Cuebiq (COVID-19 Mobility Insights 2020), religion data from the 2010 U.S. Religion Census (Grammich et al. 2018) and the 2014 Religious Landscape Study (Pew Research Center 2015), demographic characteristics from the 2018 American Community Survey: 5-Year Estimates (American Community Survey 2018) and the 2019 Bureau of Labor Statistics (Bureau of Labor Statistics 2019), stay-at-home orders 
from the New York Times (Mervosh et al. 2020), and governor's known political party. Data are limited to the contiguous United States because mobility estimates exclude Alaska and Hawaii. The District of Columbia is also omitted due to missing data on governor's political party. All measures are state-level. Our final analytic sample size is 348 (48 states*8 weeks).

\section{Measures}

\section{Mobility}

Our outcome variable is mobility. Cuebiq, an offline intelligence and measurement marketing company, partners with 86 apps to collect first-party location data to understand population behavior during the coronavirus pandemic via Software Development Kit (SDK) technology. SDK technology improves accuracy and precision in location data collection by linking with mobile phone operating systems, global positioning systems, and Wi-Fi signals. Anonymous and privacy compliant geo-behavioral data are collected for opted-in users, including movement and stops to determine dwell time and visit frequency at locations. Each day, always-on data collection accumulates, on average, 100 data points for approximately 15,000,000 cell phone users. The mobility index measures the average median distance traveled by all devices for the weeks of February 24-April 13 for each state. This time frame was selected because it marks the first period of national coronavirus awareness and changing mobility across the United States. In preliminary analyses, we assessed the construct validity of the mobility index by testing whether these scores were associated with the number of days with a state stay-at-home order. Our analyses revealed a moderate inverse association $(r=-0.45, p<0.001)$. In other words, states with longer periods of stay-at-home orders tended to exhibit lower mobility scores.

\section{Religiosity}

Our focal predictor variable is religiosity. We measure religiosity as a mean index of six variables $(\alpha=0.98)$, including (1) percent evangelical, (2) percent who report attending worship services at least weekly, (3) percent who identify as highly religious, (4) percent who say religion is very important in their lives, (5) percent who say they pray daily, and (6) the percent who say they believe in God with absolute certainty. This index assesses how religious a state is by assessing self-reported religious identities, beliefs, and practices. Percent evangelical was collected through the 2010 U.S. Religion Census: Religious Congregations and Membership Study. The remaining variables were collected through the 2014 Religious Landscape Study.

\section{Background Variables}

Our analyses include a range of state-level background variables that are at least theoretically related to mobility and religiosity, including (1) median age, (2) percent 
black, (3) the unemployment rate, (4) population density, (5) mobility lag (the mean of mobility scores for the first 2 weeks of the study period), (6) governor's political party, and (7) number of days with a state stay-at-home order. Median age, percent black, and population density are 5-year estimates from the 2018 American Community Survey. The unemployment rate for December 2019 was obtained from the Bureau of Labor Statistics. Governor's party identification is publicly available. Data on state stay-at-home orders as of April 6, 2020 were collected by the New York Times.

\section{Analysis}

Our analytic strategy proceeds in three steps. In Table 1, we present descriptive statistics for all study variables, including variable ranges, means, and standard deviations. In Table 2, we fit a model of state mobility scores using robust regression with the $\mathrm{M}$ estimator and iterated re-weighted least squares (IWLS) to downweight the influence of outliers (Jorgenson 2007; Venables and Ripley 2002). Model 1 regresses state mobility scores on dummy variables for week. This model tests whether mobility scores vary across the 8-week study period. We use dummy variables for week to capture thresholds in the association between week and mobility. Model 2 adjusts for state religiosity, median age, percent black, the unemployment rate, population density, and the mobility lag. This model tests whether state religiosity is associated with state mobility scores net of state demographic characteristics

Table 1 Descriptive statistics for selected study variables

\begin{tabular}{lccr}
\hline & Variable range & Variable mean & \multicolumn{1}{c}{ SD } \\
\hline Mobility Index (2/24-4/13) & $0.84-4.12$ & 3.07 & 0.77 \\
Mobility Index (2/24) & $3.18-4.12$ & 3.82 & 0.21 \\
Mobility Index (3/2) & $3.15-4.10$ & 3.83 & 0.21 \\
Mobility Index (3/9) & $3.12-4.09$ & 3.77 & 0.23 \\
Mobility Index (3/16) & $2.53-3.68$ & 3.13 & 0.28 \\
Mobility Index (3/23) & $0.84-3.38$ & 2.35 & 0.63 \\
Mobility Index (3/30) & $1.27-3.44$ & 2.44 & 0.56 \\
Mobility Index (4/6) & $1.95-3.58$ & 2.94 & 0.41 \\
Mobility Index (4/13) & $0.87-3.26$ & 2.27 & 0.65 \\
Religiosity (2010/2014) & $0.27-0.67$ & 0.46 & 0.09 \\
Median Age (2018) & $30.7-44.6$ & 38.32 & 2.36 \\
Percent Black (2018) & $0.004-0.38$ & 0.11 & 0.09 \\
Unemployment Rate (2019) & $2.3-6.1$ & 3.53 & 0.83 \\
Population Density (2018) & $1.29-1207.69$ & 200.75 & 263.11 \\
Mobility Lag (2/24-3/2) & $3.17-4.11$ & 3.83 & 0.21 \\
Republican Governor (2020) & $0-1$ & 0.68 & 2.92 \\
Home Order Days (2/24-4/13) & $0-7$ & 1.77 & \\
\hline
\end{tabular}

$n=348$. All measures are state-level 
Table 2 Robust regression of mobility scores (direct effects)

\begin{tabular}{|c|c|c|c|c|c|c|}
\hline & Model 1 & & Model 2 & & Model 3 & \\
\hline Week $(3 / 2)^{\mathrm{a}}$ & $\begin{array}{c}0.01 \\
(0.08)\end{array}$ & & $\begin{array}{c}0.01 \\
(0.05)\end{array}$ & & $\begin{array}{c}0.01 \\
(0.04)\end{array}$ & \\
\hline Week $(3 / 9)^{\mathrm{a}}$ & $\begin{array}{r}-0.04 \\
(0.08)\end{array}$ & & $\begin{array}{r}-0.05 \\
(0.05)\end{array}$ & & $\begin{array}{r}-0.05 \\
(0.04)\end{array}$ & \\
\hline Week $(3 / 16)^{a}$ & $\begin{array}{r}-0.69 \\
(0.08)\end{array}$ & $* * *$ & $\begin{array}{r}-0.69 \\
(0.05)\end{array}$ & $* * *$ & $\begin{array}{r}-0.68 \\
(0.04)\end{array}$ & $* * *$ \\
\hline Week $(3 / 23)^{\mathrm{a}}$ & $\begin{array}{r}-1.42 \\
(0.08)\end{array}$ & $* * *$ & $\begin{array}{r}-1.40 \\
(0.05)\end{array}$ & $* * *$ & $\begin{array}{r}-1.23 \\
(0.04)\end{array}$ & $* * *$ \\
\hline Week $(3 / 30)^{\mathrm{a}}$ & $\begin{array}{r}-1.37 \\
(0.08)\end{array}$ & $* * *$ & $\begin{array}{r}-1.35 \\
(0.05)\end{array}$ & $* * *$ & $\begin{array}{r}-1.08 \\
(0.05)\end{array}$ & $* * *$ \\
\hline Week $(4 / 6)^{\mathrm{a}}$ & $\begin{array}{r}-0.86 \\
(0.08)\end{array}$ & $* * *$ & $\begin{array}{r}-0.86 \\
(0.05)\end{array}$ & $* * *$ & $\begin{array}{r}-0.52 \\
(0.05)\end{array}$ & $* * *$ \\
\hline Week $(4 / 13)^{\mathrm{a}}$ & $\begin{array}{r}-1.53 \\
(0.08)\end{array}$ & $* * *$ & $\begin{array}{r}-1.51 \\
(0.05)\end{array}$ & $* * *$ & $\begin{array}{r}-1.19 \\
(0.05)\end{array}$ & $* * *$ \\
\hline Religiosity (2010/2014) & & & $\begin{array}{c}0.15 \\
(0.02)\end{array}$ & $* * *$ & $\begin{array}{c}0.11 \\
(0.02)\end{array}$ & $* * *$ \\
\hline Median Age (2018) & & & $\begin{array}{c}0.02 \\
(0.01)\end{array}$ & $* * *$ & $\begin{array}{c}0.02 \\
(0.01)\end{array}$ & $* * *$ \\
\hline Percent Black (2018) & & & $\begin{array}{c}0.18 \\
(0.20)\end{array}$ & & $\begin{array}{c}0.40 \\
(0.18)\end{array}$ & $*$ \\
\hline Unemployment Rate (2019) & & & $\begin{array}{r}-0.08 \\
(0.02)\end{array}$ & $* * *$ & $\begin{array}{r}-0.04 \\
(0.02)\end{array}$ & * \\
\hline Population Density (2018) & & & $\begin{array}{r}-0.0003 \\
(0.0001)\end{array}$ & $* * *$ & $\begin{array}{r}-0.0002 \\
(0.0000)\end{array}$ & $* * *$ \\
\hline Mobility Lag (2/24-3/2) & & & $\begin{array}{c}0.21 \\
(0.02)\end{array}$ & $* * *$ & $\begin{array}{c}0.20 \\
(0.02)\end{array}$ & $* * *$ \\
\hline Republican Governor (2020) & & & & & $\begin{array}{c}0.03 \\
(0.03)\end{array}$ & \\
\hline Home Order Days $(2 / 24-4 / 13)$ & & & & & $\begin{array}{r}-0.06 \\
(0.01)\end{array}$ & $* * *$ \\
\hline
\end{tabular}

All measures are state-level

$n=348 ; * p<0.05 ; * * p<0.01 ; * * * p<0.001$ (two-tailed test)

${ }^{\text {a }}$ Reference group is Week $2 / 24$

and baseline mobility scores. The question here is whether more religious states tend to exhibit higher average mobility scores. Population density and the mobility lag capture factors related to state mobility, including the concentration of populations and the average median distance traveled for the first 2 weeks of the study period. Model 3 adjusts for governor's party identification and number of days with a state stay-at-home order to assess the association between religiosity and mobility net of state political orientation and virus policy environments. 
Table 3 and Figs. 1, 2 and 3 present our moderation models. Model 1 of Table 3 adds week by religiosity interaction terms to the regression equation to formally test whether state mobility trends (weekly variations in mobility

Table 3 Robust regression of mobility scores (moderation effects)

\begin{tabular}{|c|c|c|c|c|}
\hline & Model 1 & & Model 2 & \\
\hline Week $(3 / 2)^{\mathrm{a}}$ & $\begin{array}{c}0.01 \\
(0.03)\end{array}$ & & $\begin{array}{c}0.01 \\
(0.03)\end{array}$ & \\
\hline Week $(3 / 9)^{\mathrm{a}}$ & $\begin{array}{r}-0.04 \\
(0.03)\end{array}$ & & $\begin{array}{r}-0.04 \\
(0.03)\end{array}$ & \\
\hline Week $(3 / 16)^{\mathrm{a}}$ & $\begin{array}{r}-0.69 \\
(0.03)\end{array}$ & $* * *$ & $\begin{array}{r}-0.67 \\
(0.03)\end{array}$ & $* * *$ \\
\hline Week $(3 / 23)^{\mathrm{a}}$ & $\begin{array}{r}-1.26 \\
(0.03)\end{array}$ & $* * *$ & $\begin{array}{r}-1.19 \\
(0.03)\end{array}$ & $* * *$ \\
\hline Week $(3 / 30)^{\mathrm{a}}$ & $\begin{array}{r}-1.14 \\
(0.03)\end{array}$ & $* * *$ & $\begin{array}{r}-1.03 \\
(0.04)\end{array}$ & $* * *$ \\
\hline Week $(4 / 6)^{\mathrm{a}}$ & $\begin{array}{r}-0.60 \\
(0.04)\end{array}$ & $* * *$ & $\begin{array}{r}-0.51 \\
(0.04)\end{array}$ & $* * *$ \\
\hline Week $(4 / 13)^{\mathrm{a}}$ & $\begin{array}{r}-1.31 \\
(0.04)\end{array}$ & $* * *$ & $\begin{array}{r}-1.20 \\
(0.04)\end{array}$ & $* * *$ \\
\hline Religiosity (2010/2014) & $\begin{array}{c}0.01 \\
(0.02)\end{array}$ & & $\begin{array}{c}0.03 \\
(0.02)\end{array}$ & $*$ \\
\hline Home Order Days (2/24-4/13) & $\begin{array}{c}-0.05 \\
(0.004)\end{array}$ & $* * *$ & $\begin{array}{c}-0.06 \\
(0.004)\end{array}$ & $* * *$ \\
\hline Week $(3 / 2)^{*}$ Religiosity & $\begin{array}{c}-0.001 \\
(0.03)\end{array}$ & & & \\
\hline Week (3/9)*Religiosity & $\begin{array}{c}0.01 \\
(0.03)\end{array}$ & & & \\
\hline Week (3/16)*Religiosity & $\begin{array}{c}0.11 \\
(0.03)\end{array}$ & $* * *$ & & \\
\hline Week $(3 / 23) *$ Religiosity & $\begin{array}{c}0.18 \\
(0.03)\end{array}$ & $* * *$ & & \\
\hline Week $(3 / 30) *$ Religiosity & $\begin{array}{c}0.27 \\
(0.03)\end{array}$ & $* * *$ & & \\
\hline Week $(4 / 6)^{*}$ Religiosity & $\begin{array}{c}0.18 \\
(0.03)\end{array}$ & $* * *$ & & \\
\hline Week $(4 / 13) *$ Religiosity & $\begin{array}{c}0.37 \\
(0.03)\end{array}$ & $* * *$ & & \\
\hline Home Order Days*Religiosity & & & $\begin{array}{c}0.04 \\
(0.003)\end{array}$ & $* * *$ \\
\hline
\end{tabular}

All measures are state-level. All models control for median age, percent black, the unemployment rate, population density, the mobility lag, and governor's political party

$n=348 ; * p<0.05 ; * * p<0.01 ; * * * p<0.001$ (two-tailed test)

${ }^{\text {a }}$ Reference group is Week $2 / 24$ 


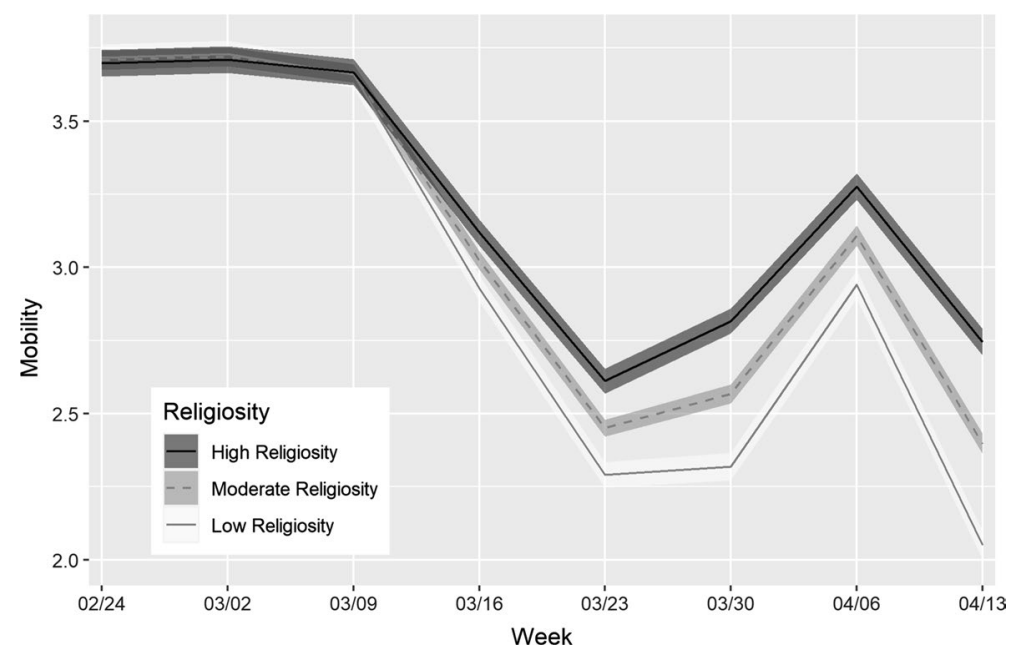

Fig. 1 Adjusted state mobility trends by state religiosity
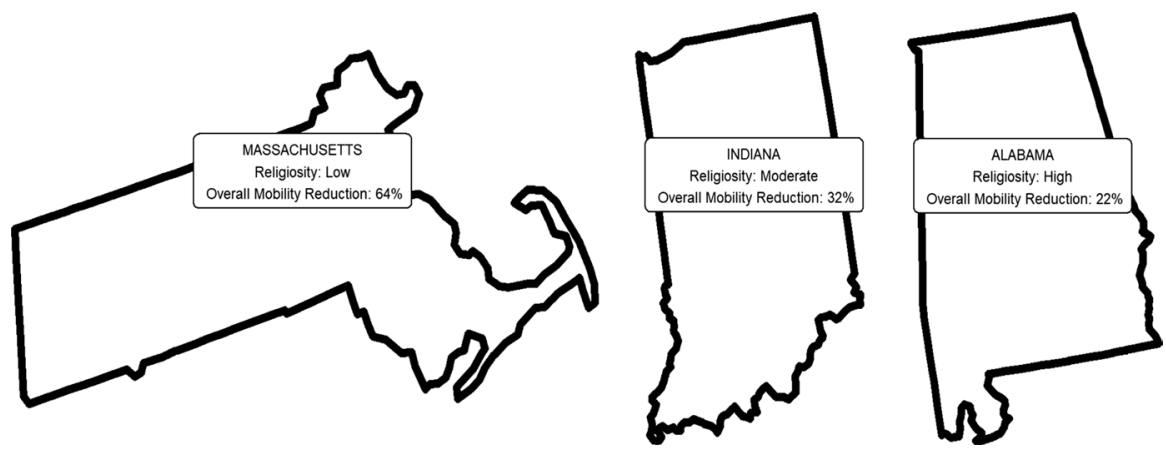

Fig. 2 Percent change in mobility (2/24-4/13) by religious exemplar states

scores) vary by state religiosity. The question here is whether state mobility scores declined at a slower rate in more religious states. Model 2 adds the interaction term for number of days with a state stay-at-home order by religiosity to test whether the association between state stay-at-home order and mobility varies by state religiosity. The question here is whether the effects of stay-at-home orders are weaker for more religious states. Figure 1 provides a graphical illustration of Model 1 (Table 3) state mobility trends by state religiosity. Figure 2 presents overall mobility reductions (changes between the first and last week of the study period) for three exemplar states, one of low, moderate, and high religiosity. Finally, Fig. 3 provides a graphical illustration of the stay-at-home order*religiosity interaction terms in Model 2 (Table 3). 


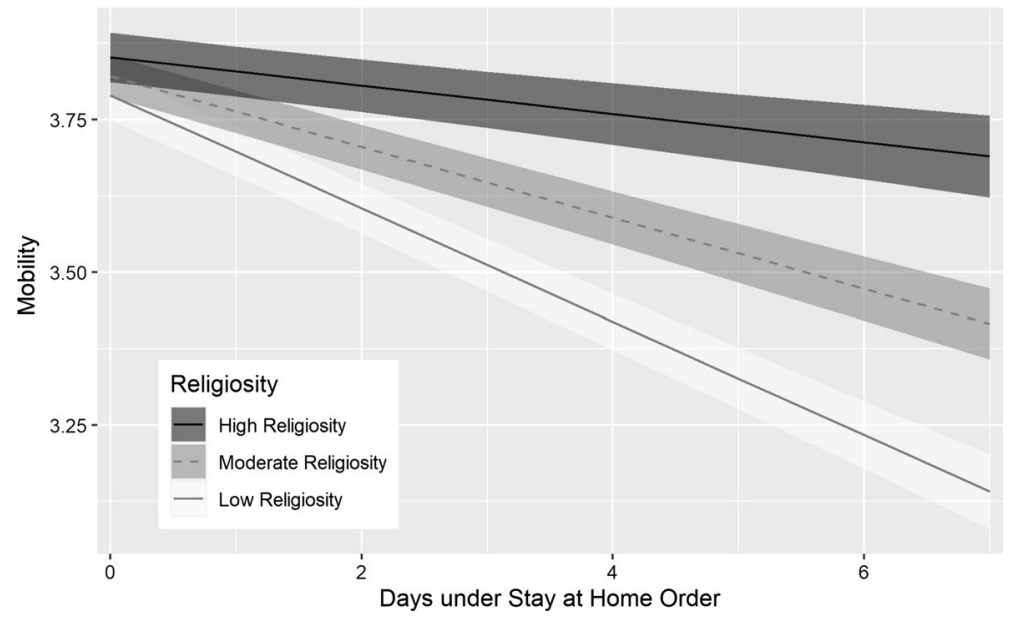

Fig. 3 Adjusted state mobility by days under stay-at-home order and state religiosity

\section{Results}

\section{Descriptive Statistics}

In Table 1, we see an overall trend toward declining state mobility scores over the study period. State mobility was highest during the weeks of February 24 and March 2. From March 2 to March 23, we observed the first trend toward declining state mobility. After a short period of slightly increasing state mobility from March 23 to April 6, we recorded our lowest mobility scores yet for the week of April 13.

\section{Direct Effects}

In Table 2, Model 1 compares mobility scores for the first week (February 24) of our study period to each of the 7 weeks from March 2 to April 13. We observe that mobility scores for the week of February 24 are comparable to those for the weeks of March 2 and March 9. We then find lower mobility scores for the weeks of March 16 to April 13 than for the week of February 24.

Model 2 reveals higher state mobility scores for states that are more religious, older, and more mobile at the beginning of the study period (February 24-March 2). We also see lower state mobility scores for states with generally higher unemployment rates and greater population density. Mobility scores do not appear to vary by percent black in this model.

Model 3 shows that state mobility scores are lower in states with longer periods of state stay-at-home orders. State mobility scores do not appear to vary by Governor's party identification in this model. In short, state mobility scores are comparable for states with Republican and Democratic Governors. 


\section{Moderation Effects}

In Table 3, the interaction terms in Model 1 suggest that, compared to the week of February 24, state mobility scores declined at slower rates in more religious states for five of the 8 weeks under study (March 16-April 13). Model 2 of Table 3 indicates that the inverse association between number of days with a state stay-at-home order and mobility is less pronounced in more religious states.

Figure 1 represents how mobility for three levels of religiosity changed over the 8-week study period, controlling for all covariates. From March 16 to April 13, states with high religiosity exhibited the highest state mobility scores. Figure 2 presents the percent reduction in overall state mobility scores between the weeks of February 24 and April 13 for three exemplar states. From the first week to the last week of the study period, state mobility scores declined by $22 \%$ for Alabama (high religiosity), by $32 \%$ for Indiana (moderate religiosity), and by $64 \%$ for Massachusetts (low religiosity). Finally, Fig. 3 clearly demonstrates that state stay-at-home orders had a weaker impact on mobility in more religious states.

\section{Supplemental Analyses}

In supplemental analyses, we estimated our regression models using ordinary least squares regression with cluster robust standard errors for state (Robitzsch and Grund 2020) to assess potential violations of regression assumptions (serial correlation and heteroscedasticity). The results were substantively identical to our robust regressions models. In other sensitivity analyses, we controlled for total population size, percent Hispanic, percent with a college degree, per capital income, income inequality (Gini coefficient), and percent obese. In each case, the additional variable was either unrelated to mobility or failed to alter any of our substantive conclusions.

\section{Discussion}

In this paper, we considered the association between state religiosity and state mobility scores during the coronavirus (COVID-19) pandemic. Our first hypothesis (H1) specified that more religious states would tend to exhibit higher average mobility scores. In support of this hypothesis, our analyses showed that more religious states tended to travel more than less religious states during the pandemic. This general pattern persisted with adjustments for median age, percent black, the unemployment rate, population density, a mobility lag, governor's political party identification, and number of days with a state stay-at-home order. Our second hypothesis (H2) indicated that state mobility scores would decline at slower rates in more religious states. Consistent with this hypothesis, our analyses revealed that reductions in travel during the pandemic were, on average, smaller in more religious states. Our final hypothesis (H3) stated that the inverse 
association between number of days with a state stay-at-home order and mobility scores would be less pronounced in more religious states. In accordance with this hypothesis, we observed that religious states were more resistant to stay-at-home orders.

To our knowledge, this is the first empirical study of religious contextual variations in coronavirus pandemic behavior. Our findings are important because they seem to confirm the suspicion that religious populations and communities may be especially likely to acquire and spread the coronavirus. In the context of a pandemic, the risk may be even more pervasive. Religious states include people who are religious and people who are not. Because the coronavirus is so highly contagious, any ideological resistance to public health recommendations could present an existential threat to society. We need to begin to think about ways of overcoming religious cultural barriers to critical pandemic responses. Potential strategies or interventions must systematically address obstacles related to the mistrust of science, religious authority, and religious liberty.

We acknowledge that our analyses are limited in three key respects. Although our data suggest that more religious states tend to be more mobile during the coronavirus pandemic, we cannot conclude that religious individuals are more mobile without individual-level data. Because we are currently in the early stages of the pandemic, we are unable to assess concurrent changes in our state-level predictors across years. Finally, our mobility data are also limited in the sense that they are based on geo-behavioral data for opted-in users, not probability samples in states. We are nevertheless encouraged by the fact that our mobility scores are predictably associated with a range of variables, including median age, the unemployment rate, population density, a mobility lag, and number of days with a state stay-at-home order.

Despite these limitations, we provided the first empirical study of state religiosity and mobility during the coronavirus pandemic. Our analyses consistently showed that, in the early weeks of the pandemic, religious states tended to travel more and were more resistant to changing their movement patterns. Our analyses are important because they contribute to our understanding of the social patterning of pandemic mobility, which is ultimately relevant to slowing the spread of the coronavirus. More research is needed to replicate our findings using longer longitudinal designs and data collected at different levels of analyses, including the county and individual levels. As more valid and reliable epidemiological data become available, we will need to assess whether state infection and mortality rates also vary according to state religiosity. Future work should continue to consider the social patterning of pandemic mobility more broadly. Understanding the role of state political environments is perhaps most pressing. Research along these lines would provide a more thorough understanding of the impact of social and ideological forces on pandemic behavior.

Funding None. 


\section{Compliance with Ethical Standard}

Conflict of interest The authors declare that they have no conflict of interest.

Human and Animal Rights and Informed Consent Because this article employs secondary data that were previously collected de-identified data to protect respondents, it was exempt from human subjects review. When the study was collected, informed consent was obtained from all individual participants. No animals were included in the study.

\section{References}

American Community Survey. (2018). American Community Survey: 5-Year Estimates. https://www. census.gov/programs-surveys/acs/news/data-releases/2018/release.html\#par_textimage

Boone, Kathleen. (1989). For the bible tells them so: The discourse of fundamentalism. Albany: State University of New York Press.

Brown, L. (2020). Virginia pastor who defiantly held church service dies of coronavirus. New York Post 4/13. https://nypost.com/2020/04/13/virginia-pastor-who-held-packed-church-service-dies-of-coron avirus/

Bureau of Labor Statistics. (2019). The economics daily. https://www.bls.gov/opub/ted/2020/unemp loyment-rates-in-15-states-were-lower-than-the-3-point-5-percent-u-s-rate-in-december-2019.htm

Centers for Disease Control and Prevention. (2020). How to protect yourself \& others. https://www.cdc. gov/coronavirus/2019-ncov/prevent-getting-sick/prevention.html

Collier, K., Davila, V., \& Trevizo, P. (2020). Meet the pastors holding in-person services during coronavirus. ProPublica 4/2. https://www.propublica.org/article/meet-the-pastors-holding-in-person-servi ces-during-coronavirus?utm_source=pardot\&utm_medium=email\&utm_campaign=majorinves tigations

COVID-19 Mobility Insights. (2020). Cuebiq's mobility index analysis. https://help.cuebiq.com/hc/en-us/ articles/360041285051-Cuebiq-s-COVID-19-Mobility-Insights

Curtis, E. (2020). Pastors corner: COVID-19-JOSHUA 1:9. Havre Daily News 3/20. https://www.havre dailynews.com/story/2020/03/20/local/pastors-corner-covid-19-joshua-19/528064.html

Edwards, D. (2020). "I'm covered in Jesus' blood": Defiant churchgoer tells CNN she can't get sick because she's Christian. Raw Story 4/5. https://www.rawstory.com/2020/04/im-covered-in-jesus -blood-defiant-churchgoer-tells-cnn-she-cant-get-sick-because-shes-christian/

Ellison, C., Bartkowski, J., \& Segal, M. (1996). Conservative Protestantism and the parental use of corporal punishment. Social Forces, 74, 1003-1028.

Ellison, C., \& Musick, M. (1995). Conservative Protestantism and public opinion toward science. Review of Religious Research, 36, 245-262.

Evans, J. (2013). The growing social and moral conflict between conservative Protestantism and science. Journal for the Scientific Study of Religion, 52, 368-385.

Evans, J., \& Evans, M. (2008). Religion and science: Beyond the epistemological conflict narrative. Annual Review of Sociology, 34, 87-105.

Gattis, P. (2020). Lee County coronavirus hotspot's common factor? Church, hospital says.AL.com 3/26. https:/www.al.com/news/2020/03/lee-county-coronavirus-hotspots-common-factor-church-hospi tal-says.html

Gauchat, G. (2008). A test of three theories of anti-science attitudes. Sociological Focus, 41, 337-357.

Gauchat, G. (2012). Politicization of science in the public sphere: A study of public trust in the United States, 1974 to 2010. American Sociological Review, 77, 167-187.

Gowen, A. (2020). Cronavirus deniers and hoaxers persist despite dire warnings, claiming 'it's mass hysteria'. The Washington Post 3/19. https://www.washingtonpost.com/national/coronavirus-deniersoutbreak-hoax/2020/03/19/46bc5e46-6872-11ea-b313-df458622c2cc_story.html

Grammich, C., Hadaway, K., Houseal, R., Jones, D., Krindatch, A., Stanley, R., Taylor, R. (2018). U.S. Religion Census: Religious Congregations and Membership Study, 2010 (State File). http://www. thearda.com/Archive/Files/Descriptions/RCMSST10.asp 
Jorgenson, A. (2007). Foreign direct investment and pesticide use intensity in less-developed countries: A quantitative investigation. Society and Natural Resources, 20, 73-83.

Keating, D., \& Esteban, C. (2020). COVID-19 is rapidly becoming America's leading cause of death. The Washington Post 4/16. https://www.washingtonpost.com/outlook/2020/04/16/coronavirus-leadi ng-cause-death/?arc404=true

Mazzei, P. (2020). Florida pastor arrested after defying virus orders. The New York Times 3/30. https:// www.nytimes.com/2020/03/30/us/coronavirus-pastor-arrested-tampa-florida.html

Mervosh, S., Lu, D., \& Swales, V. (2020). See which states and cities have told residents to dtay at home. https://www.nytimes.com/interactive/2020/us/coronavirus-stay-at-home-order.html

Pew Research Center. (2015). America's changing religion landscape. https://www.pewforum.org/relig ious-landscape-study/

Robitzsch, A., \& Grund, S. (2020). miceadds: Some additional multiple imputation functions, especially for "mice". R package version 3.8-9. https://CRAN.R-project.org/package=miceadds

Rosen, D. (2020). God's vengeance: The Christian right and the coronavirus. CounterPunch 3/27. https:// www.counterpunch.org/2020/03/27/gods-vengeance-the-christian-right-and-the-coronavirus/

Sherkat, D. (2011). Religion and scientific literacy in the United States. Social Science Quarterly, 92, 1134-1150.

Sherkat, D. (2017). Religion, politics, and Americans' confidence in science. Politics and Religion, 10, $137-160$.

Sherkat, D., \& Ellison, C. (2007). Structuring the religion-environment connection: Identifying religious influences on environmental concern and activism. Journal for the Scientific Study of Religion, 46, 71-85.

Slisco, A. (2020). Pastor holds service with over 1,000 parishioners in defiance of large-gathering ban. Newsweek 3/18. https://www.newsweek.com/pastor-holds-service-over-1000-parishoners-defiancelarge-gathering-ban-1493113

Smiley, K. (2019). A polluting creed: Religion and environmental inequality in the United States. Sociological Perspectives, 62, 980-1000.

Stewart, K. (2020). The religious right's hostility to science is crippling our coronavirus response. The New York Times 3/27. https://www.nytimes.com/2020/03/27/opinion/coronavirus-trump-evangelica ls.html

The Hopi Tribe. (2020). Information regarding the coronavirus COVID-19 outbreak. https://www.hopinsn.gov/information-regarding-the-coronavirus-covid-19-outbreak/

Venables, W., \& Ripley, B. (2002). Modern Applied Statistics with S. New York: Springer.

Wise, T. (2020). Americanism is a pandemic's BFF. Medium 3/29. https://medium.com/@ timjwise/ameri canism-is-a-pandemics-bff-59e1f31e1365

Publisher's Note Springer Nature remains neutral with regard to jurisdictional claims in published maps and institutional affiliations. 